University of Miami Law School

University of Miami School of Law Institutional Repository

1990

\title{
Lowering One's Cites: A (Sort of) Review of the University of Chicago Manual of Legal Citation
}

Mary I. Coombs

University of Miami School of Law, mcoombs@law.miami.edu

Follow this and additional works at: https://repository.law.miami.edu/fac_articles

Part of the Legal Writing and Research Commons

\section{Recommended Citation}

Mary I. Coombs, Lowering One's Cites: A (Sort of) Review of the University of Chicago Manual of Legal Citation, 76 Va. L. Rev. 1099 (1990).

This Article is brought to you for free and open access by the Faculty and Deans at University of Miami School of Law Institutional Repository. It has been accepted for inclusion in Articles by an authorized administrator of University of Miami School of Law Institutional Repository. For more information, please contact library@law.miami.edu. 


\title{
LOWERING ONE'S CITES: A (SORT OF) REVIEW OF THE UNIVERSITY OF CHICAGO MANUAL OF LEGAL CITATION ${ }^{1}$
}

\author{
Mary I. Coombs ${ }^{2}$
}

Traditionally, law review articles have grappled with the substance of the law, embodied in the texts of either judicial opinions or other law review articles. More recently, serious attention occasionally has been paid to matters that might once have seemed peripheral-the style in which ideas are expressed (or hidden) and the marginalia of prior writings. In particular, footnotes, once considered beneath contempt, have been raised into the prominence of text ${ }^{3}$ (though some of the old school may enumerate the trend as one of descending to the lowest common denommator ${ }^{4}$ ).

1 Cf. Rodell, Goodbye to Law Reviews, 23 Va. L. Rev. 38, 44 (1936) (noting, after excoriating law review style, that

[w] hen it counes to the book reviews, coinpany manners are not so strictly enforced and it is occasionally possible to talk out loud or crack a joke. As a result, the book reviews are stuck away in the back like country cousins and anyone who wants to take off his slioes and feel at lome in a law review will do well to come in by way of the kitchen.).

2 Professor of Law, Umiversity of Miami. J.D. University of Michigan, 1978. I want to thank the inany friends-most of whoun no doubt wish to remain anonymous-wliose wit and/or wisdom contributed to the development of this Review. The occasional politics of the (usually) first footnote-to advance the author's plans to stay at (or move from) her present imstitution-are thus necessarily absent from this footnote. (A cf., e.g., citation here to any particular source at note 1 would be contrary to deeency and self-preservation.) Such issues are, furthermore, beyond (or before) the scope of this Book Review. See generally Austin, Footnotes as Product Differentiation, 40 Vand. L. Rev. 1131, 1145-47 (1987) (briefly describing use of first footnotes to indicate those witl whom one wishes to be associated); Dalton, The Clouded Prism, 22 Harv. C.R.-C.L. L. Rev. 435, 442 \& n.19 (1987) (citing authors who have poked fun at footnote 1 ).

I also want to recognize my student editor, who can decide for herself if she wishes to remain anonymous. No one privy to our discussions of the minutiae of, for example, when a space is required in a citation, would believe that both of us find the whole process to be a bureaucrat's variant of theater of the absurd.

3 Really should see Balkin, The Footnote, 83 Nw. U.L. Rev. 275 (1989) (a deconstruction of footnotes and especially of footnote four of United States v. Carolene Prods. Co., 304 U.S. 144 (1938), in the form of an extended footnote four). This and other unconventional signals are explained at the end of this Book Review. Trust me.

4 Footnotes may be low, but they are frequently not least. See, sort of, Ellman, A Comparison of Law Faculty Production in Leading Law Reviews, $33 \mathrm{~J}$. Legal Educ. 681, 688 
The shift in emphasis to form and fringe is not restricted to a single field but obtains in most academic disciplines. In particular, I suggest, there has been a general revolution in which commentary has become subject matter and footnote has become text. The intellectual banner under which this revolution has been fought is deconstruction, a movement that msists that the gaps and corners and shppages in texts-the words not chosen-are as important to its meaning as the "central ideas" studied in traditional forms of interpretation. The guerilla leading this revolution has been Jacques Derrida. ${ }^{5}$ The ideas of Derrida or, perhaps more precisely, the Idea of Derrida, has begun to influence legal writing. ${ }^{6}$

The contents-or at least the existence-of footnotes in legal writing has been a topic of marginal interest for some time. A tradition of sniping at the overwritten, over-footnoted style of legal writing can be traced back at least as far as the Legal Realists, ${ }^{7}$ and has continued to this day. ${ }^{8}$ Tenured professors and judges have attacked this manner of legal writing directly, while

Table 4 (1983) (ranking faculty productivity at different law schools, inter alia, by the total number of footnotes in articles they had published in leading law reviews during the sample period).

The most heavily footnoted article I had seen before preparing this footnote was Choper, Consequences of Supreme Court Decisions Upholding Individual Constitutional Rights, 83 Mich. L. Rev. 1 (1984) (1611 footnotes). Choper, however, was apparently a mere temporary interloper. Earlier that year, Arnold Jacobs had published The Meaning of "Security" Under Rule 10b-5, 29 N.Y.L. Sch. L. Rev. 211 (1984), with 1247 footnotes. Jacobs easily regained the title after the Choper challenge with An Analysis of Section 16 of the Securities Exchange Act of 1934, 32 N.Y.L. Sch. L. Rev. 209 (1987) (4824 footnotes).

The various pieces comprising Harvard Developments in the Law may also be in the running for this dubious honor. The total number of footnotes in these collections, however, cannot be determined by simply turning to the last page of the Development, since each major section is separately footnoted. Thus, for example, Developments im the Law-Zoning, 91 Harv. L. Rev. 1427 (1978) contains $(88+143+183+264+113+77+207+395)$ 1470 footnotes. A Uniform System of Citation (14th ed. 1986) [heremafter Bluebook (or Bluebook followed by the edition number, if other than the 14th ed.)], another Harvard Law Review Association product, is confusing in its solution to the conundrum of how to crossreference to the text at a particular numbered footnote in a source that has several, for example, n.17's. See Bluebook, supra, at 21 (Rule 3.6). This rule, prescribing how to provide cross-references, seems to assume that a reference to "text accompanying note 17" would be clear. The Harvard Developments, however, could logically contain a footnote that said: "See infra text accompanying note 17 . But see supra text accompanying note 17."

5 Pretend to have seen randomly, e.g., J. Derrida, Of Grammatology (1976); Derrida, Limited Inc abc . . , 2 Glyph 162 (1977). See infra p. 1109 on meaning of the signals "pretend to have seen" and "randomly."

6 See, e.g., Balkin, supra note 3.

7 A classic is Rodell, supra note 1.

8 E.g., Rodell, Goodbye to Law Reviews-Revisited, 48 Va. L. Rev. 279 (1962); Mikva, Goodbye to Footnotes, 56 U. Colo. L. Rev. 647 (1985); Posner, Goodbye to the Bluebook, 53 U. Clii. L. Rev. 1343 (1986). [Note to editors: please do not rearrange this chronological list, 
embodying an almost footnote-free "purity." In contrast, University of Pennsylvania Law Review guerrillas-in-training have twice attacked with the weapon of heavy-handed (or heavy-footed) irony. ${ }^{10}$

The content of footnotes and the issue of whether certain nuaterial should be in text or in footnote has also been the basis for ninumerable nnpublicized battles. ${ }^{11}$ Soine of these have been substantive; others, at least partly formal, were fought with the Bluebook as a weapon. ${ }^{12}$ Authors unwilling to follow its dictates traditionally had no counter-weapons but the force of their intellect, a soinewhat inept sword for battling over such issues as the correct

a.k.a The Long Goodbye, in accordance with the dictates of the Bluebook, supra note 4, at 12 (Rule 2.4(h)). See Posner, supra, at 1347.]

The bad repute of law review writing is perhaps nowhere clearer than in the admission of one of its few defenders that the bad writing of law reviews "rarely renders the articles impossible to decipher." Martin, The Law Review Citadel: Rodell Revisited, 71 Iowa L. Rev. 1093, 1098 (1986).

9 Rodell avoided footnotes entirely in his first article. See Rodell, supra note 1 . The second had only the by-then-obligatory asterisk footnote to identify and credential the author. It also proudly announced the author's near-perfect rccord at avoiding the pesky critters in the rest of his works. Rodell, supra note 8 , at 287 . (Thus, Rodell's articles, in striking contrast to most law review writing, inay well be hittle noted, but long remeinbered.) Judge Mikva, supra note 8 , has that first asterisk footnote plus an ironic, sole, and final " $n .4$ " (see, of course, United States v. Carolene Prods. Co., 304 U.S. 144 (1938)). Judge Posner, supra note 8, has seven footnotes in addition to the introductory one-a dechne from the absolutist rigor of his predecessors but, at a rate of less than one per page, far below the average for law review writing. Ellman, supra note 4, at 683 , calculates the average number of footnotes per page in his sample of leading law reviews to range from 2.9 to 4.3. While this data might well confirm Rodell's curmudgeonliness, Ellman suggests that the total number of footnotes published in such law reviews is the best objective ineasure of scholarly rank. Id. at 689.

10 Aside, The Common Law Origins of the Infield Fly Rule, 123 U. Pa. L. Rev. 1474 (1975) [hereinafter Don't Fly]; Aside, Don't Cry Over Filled Milk: The Neglected Footnote Three to Carolene Products, 136 U. Pa. L. Rev. 1553 (1988) [hereinafter Don't Cry].

Although The University of Pennsylvania Law Review is a co-copyright holder in the Bluebook, it is Harvard Law Review with which it is inevitably associated. Perhaps, then, it is natural that such guerrilla attacks on the Bluebook should appear at Harvard only in what the Harvard Law Review imight consider a subordinate journal. See Strasser, Technical Due Process: ? (Book Review), 12 Harv. C.R.-C.L. L. Rev. 507 (1977) (reviewing Bluebook (12th ed. 1976)). But cf. Book Note, 101 Harv. L. Rev. 1323 (1988) (reviewing The University of Chicago Manual of Legal Citation).

11 Some choice fragments end up neither in text nor footnote but wait, like orphaned children, in their parents' word processor, for another article to adopt thein.

12 Prior to the introduction of the Maroon Book, see infra note 18, the Bluebook clearly reigued supreme. It 'has been called the 'pioneer' manual, the 'Bible,' the 'final arbiter,' even the 'Kama Sutra' of legal citation." Cooper, Anglo-American Legal Citation: Historical Developinent and Library Implications, 75 L. Libr. J. 3, 21 (1982) (footnotes omitted: if you are coinpulsive enough to care, look it up). 
parenthetical or introductory signal. ${ }^{13}$ Thus, most law review authors, whatever their private moans and protests, rarely made an issue of such formalities. ${ }^{14}$ Rather, like sheep, they were controlled by the student editors who had deigned to publish their work. ${ }^{15}$ They, in turn, deferred to the other student editors who had invented the Bluebook ${ }^{16}$ and are the current guardians of its Pythian flame. Particularly stubborn folks could engage in the game of acadeınic chicken available to both author and review staff in the latter stages of the publication process, but applying this to the Bluebook

13 Perhaps my favorite story of this sort involves my colleague, Richard Michael Fischl. In his article, Self, Others, and Section 7: Mutualism and Protected Protest Activities Under the National Labor Relations Act, 89 Colum. L. Rev. 789 (1989), as accepted by the Review, he had said: "[W] hatever the case with Holmes's dog, employees would prefer to be neither kicked nor tripped over." Id. at 803-04 n.41. Whatever has been achieved in the way of a common law, we apparently lack a common vocabulary; the reference to Holmes's dog, the editors asserted, must be spelled out. Professor Fischl did so, but, in the next draft, he included an author's revenge: "See O. Holmes, The Common Law 3 (1881)." Id. Don't you wish you could see prior drafts of id. ("discussing late nineteenth century pet care practiees"). The editors, presumably in jest, asked if this was an accurate reading of Holmes's meaning; they were not so anal-retentive as to require a parenthetical indicating that "tripped over" had been substituted for Holmes's "stumbled over."

See also your own "additional sourcc material that supports the proposition," starring the intransigent, stubborn, obstreperous author/editor of your choice.

14 Experienced law professors have learned the art of negotiating with editors and citecheckers. They will yield reluctantly on issues of no real significance, see infra note 25 , in order to kecp the arguinents or phraseology they really care about, see infra note 32 (unchanged froin prior drafts). The excessively clever may even include dehiberate errors to provide cite-checkers with an easy sense of accomplishinent.

15 Law school hiring practices ensure that inany faculty theinselves served tine as law review editors. Subinitting to the dictates of the current crop of editors nay be felt as a validation of our own pasts rather than as a form of poetic(?) justicc(?). Cf. Austin, Footnote Skulduggery and Other Bad Habits, 44 U. Miami L. Rev. - (forthcoming 1990) (describing process by which law review editors are acculturated into footnote-philia). (The working cite to this article was "some issue of the Miami L. Rev. that my students had better get into page proofs soon. Cf. infra note 57 (on citing collcagues' working drafts).)

16 Bluebook, supra note 4 (1st ed. 1926). This edition, only 30 pages long, was relatively simple in its directives. The editors of the fourteenth edition have suggested that citation manuals, like other bureaucratic products, may inevitably metastasize. Comments of Christina Uhlrick at panel on proper citation form at National Conference of Law Reviews (University of Toledo, 1989) [hereinafter Law Review Conferencc] (tape available from author, but see infra note 57 and accoinpanying text).

Given the length of the Bluebook, one is surprised to find a gap in its prescriptions. Yet the correct citation form for a book like the Bluebook, lacking listed author or editor, is unclear. See Bluebook, supra, at 84 (Rule 15.1: "If a work has no named editor, it may be necessary to desiguate an edition by the name of the publisher) (emphasis added). Pretend to have cf.'ed Godel's theore1n, discussed in, e.g., D. Hofstadter, Godel, Escher, Bach: An Eternal Golden Braid (1979) (describing Godel's theoren, which shows that complex mathenatical systens can never be both self-contained and complete). 
issues of citation form seems rather like hunting gnats with an elephant gun. ${ }^{17}$

Recently, however, the battlefield has been altered by the publication of a new competitor, The Umiversity of Chicago Manual of Legal Citation. ${ }^{18}$ The determination by University of Chicago students to compete, and thereby allow the market to decide which is the more efficient guide to legal citation, seems entirely apt, ${ }^{19}$ as does the cooperation with the profit-making sector indicated by the choice of publishers. ${ }^{20}$ The differences in substance between the two enterprises are also striking.

Richard Posner, in his laudatory essay introducing the Maroon Book, ${ }^{21}$ summed up quite accurately the basic differences between the two manuals.

17 See, sort of, metaphor in preceding paragraph; see also, sort of, for similarly mixed metaphor of shotgun type attacks on the law review merry-go-round, Rodell, supra note 8 , at 287 (followed by the unapologetic: "As a metaphor-mixer from way back, I remind you that the merry-go-round is handy by the shooting gallery. ...").

18 The University of Chicago Manual of Legal Citation (U. Chi. L. Rev. \& U. Chi. Legal F. eds. 1989) [hereinafter Maroon Book; the temptation to be less color-precise and refer to it as the University of Chicago's "Little Red Book" is almost, but not quite, overwhelming].

19 The Bluebook has been called a monopoly. Given the role of its law review authors in determining citation form within their own pages, it might be viewed more accurately as the product of a cartel. The difference is significant. For example, at first the Bluebook imposed its authors' will absolutely regarding type faces. Bluebook, supra note 4, at 97-98 (11th. ed. 1967). As law reviews began to defect, the Bluebook softened its stand. Large and small capitals were "generally used," but it reluctantly acknowledged that, "[i]f a publication has decided not to use that typefaee, ordinary roman type should be used in its place." Bluebook, supra note 4, at 1 (12th ed. 1976). By now, the Bluebook authors have given up. They provide three options, noting that "[l]aw reviews use various typeface conventions." Bluebook, supra note 4, at 5. Cf., for the hell of it, e.g. Easterbrook, The Limits of Antitrust, 63 Tex. L. Rev. 1, 27 (1984) (on the instability of cartels). Others have noted the aptness of antitrust metaphors for legal forms. Austin, supra note 2.

The Maroon Book has opted for prescriptive simphicity: "[a]ll material should appear in roinan type" except when italicizing case names and book and article titles. Maroon Book, supra note 18, at 9. The Maroon Book also explicitly authorizes authors to use italics for "words to be emphasized." Id. That such authorization was felt necessary may suggest the constricting power of citation manuals.

20 The Maroon Book is published by Lawyers Co-operative Publishing Company, BancroftWhitney Company and Mead Data Central, Inc., Maroon Book, supra note 18, at 1; the Bluebook is published by the Harvard Law Review Association, Bluebook, supra note 4, at ii.

21 Posner, supra note 8. Posner praises the Maroon Book, inter alia, for calling on authors to include the first names of cited authors, since this may help the reader deeide "how much weight he wants to give the citation." Id. at 1345 . Such information is only relevant in a middle range, however. It is of no value to the thoroughly ignorant (except to indicate (usually) gender) and unnecessary to the cognosccnti. Would Judge Posner otherwise be unsure whether a particular title was by Ronald or Andrea Dworkin? Joe Singer's solidaritybased rationale for providing full names strikes me as more persuasive than Judge Posner's informational market argnment. [Joseph William] Singer, Persuasion, 87 Mich. L. Rev. 2442, 2442 n.* (1989). 
The Bluebook is highly particularistic, formalistic, and prescriptive; to the extent possible, rules are given for every conceivable citation problem. ${ }^{22}$ The mass of particular rules, however, has made the Bluebook so lengthy and complex, that its own purpose-lielping both writer and reader-has been defeated. ${ }^{23}$ The Maroon Book, by contrast, is far more open-ended (and, perhaps as important, far shorter). It suggests rather than orders, and it leaves many decisions up to the author, depending on the particular needs of the text. ${ }^{24}$

The contrast between the Bluebook and Maroon Book recapitulates a tension existing throughout law: that between rules and standards. ${ }^{25}$ Interestingly, it is the Harvard-led manual that opts for rules. ${ }^{26}$ Indeed, its prescriptive character has apparently increased at the same time that

22 No citation is really necessary here; even if I'm not certifiably reliable, the statement already carries the legitimacy of a pronouncement by Judge Posner. Nonetleless, those who value what Fred Rodell, supra note 1, at 40, called the "probative or if-you're-from-Missourijust-take-a-look-at-all-this type" footnote, may accord, e.g., Benton, Developments in the Law-Legal Citation (Book Review), 86 Yale L.J. 197 (1976) (reviewing twelftl edition of the Bluebook); Lushing, Book Review, 67 Colum. L. Rev. 599 (1967) (reviewing eleventli edition of the Bluebook).

23 A guide to the Bluebook, repeating its admonitions in somewliat simpler language, is available. M. Ray \& J. Ramsfield, Legal Writing: Getting it Right and Getting it Written (1987).

24 The only review of the Maroon Book in a dismterested law review suggests that its radical surgery may go too far. Cornwell, Book Review, 21 J. Marsliall L. Rev. 233 (1987). The value of that review is called somewhat into question by its criticism of the Maroon Book for including the suggestions on style in Posner, supra note 8. If this is a problem, it is readily avoided by purchasing the pamphlet ratler than, as proposed in the review, benig more "costefficient" and photocopying the version im the Chieago Law Review.

The Maroon Book was also subject to a review in the Harvard Law Review. Book Note, supra note 10. The review is, on the whole, unfavorable, but the editors are discreet: there is no indication in the table of contents pages that the book is being reviewed, apparently avoiding the noticc of the Index of Legal Periodicals. Will not see in, e.g., 27 Index to Legal Periodicals (1988).

25 See, e.g., Kennedy, Form and Substance in Private Law Adjudication, 89 Harv. L. Rev. 1685 (1976) [hereinafter Form and Substance]. Contra Gabel \& Kennedy, Roll Over Beetlioven, 36 Stan. L. Rev. 1, 15 (1984) (renouncing fundamental contradiction at heart of Form and Substance, supra).

See, for the liell of it, Dalton, supra note 2, at 444-45 (discussing appropriateness of white intellectual's appropriation of Chuck Berry's lyrics). But sec [this is all the word association games the editors will let me get away with].

Note: at this juncture, the book review editor and I disagreed veliemently over whether the proper introductory signal to Gabel \& Kennedy, supra, was "contra" or "but see." Neither of us could articulate clearly the difference between the two. The editor prevailed.

26 Cf. Strasser, supra note 10, at 509 (criticizing twelftl edition for exalting teclinical over substantive due process). The Maroon Book's approach is readily explicable with a different analogy. The editors have replaced per se rules with a generalized rule of reason. Cf. $R$. Posner, Antitrust Law 165-66 (1976) (advocating such change in regard to distribution 
Harvard faculty have been in the forefront of attacks on formalism. ${ }^{27}$ The gracious suggestion that "[w] henever clarity will be served, the citation form should be altered without hesitation," was deleted in the eleventh edition ${ }^{28}$ and never seen again. ${ }^{29}$

The Chicago manual is far more permissive. "[B]ecause it is neither possible nor desirable to write a particular rule for every sort of citation problem that might arise, the rules leave a fair ainount of discretion to practitioners, authors, and editors." 30 The rules/standards debate, however, is much more complex than a smiple battle of left against right. As certain minority critics of the Critical Legal Studies movement have forcefully pointed out, formal rules can sometimes provide a bulwark to protect the interests of minorities and other dispossessed groups. By contrast, a legal regime without any absolute rules can be manipulated more easily by people with power. ${ }^{31}$ The discretion provided by the Maroon Book will no doubt be exercised by Judge Posner in any of his published works. It is unlikely to benefit the poor schlemiel from some second-ranked law school whose submission is bemg edited by the student editors of the Chicago Law Review. ${ }^{32}$

A comparison of these citation manuals provides an occasion, or at least an excuse, for considerimg the meaning and value of one element of legal writing that has remained almost unexanimed in the august (or, in some cases, mayan or julian) pages of law reviews: the format of the footnote. In particular, I want to consider those pesky little siguals at the beginning of most footnotes. ${ }^{33}$

Whether the purposes of siguals are better served by the complex of rules in the Bluebook or the looser style of the Maroon Book depends on what those purposes are. The traditional understandings of the "legal citation" are that its purpose is "to lead its reader to the work cited" 34 or "to give credit for borrowed material [and] to provide the reader with access to

agreements). Since I have never undergone the ministrations of a Maroon Book edit, I cannot say whether, in practice, its suggestions have ossified into rules.

27 Really should see, but at least pretend to have seen, e.g., M. Horwitz, The Transformation of American Law 1780-1860 (1977); Form and Substance, supra note 25;

Kennedy \& Michelman, Are Property and Contract Efficient?, 8 Hofstra L. Rev. 711 (1980).

${ }^{28}$ Lushing, supra note 22, at 600 (quoting Bluebook, at iv (10th ed. 1958)).

29 Trust me, I've looked it up.

30 Maroon Book, supra note 18, at 7.

31 See, e.g., Minority Critiques of the Critical Legal Studies Movement, 22 Harv. C.R.-C.L.

L. Rev. 297 (1987).

32 Examples deleted to protect the innocent-and the powerful.

33 See, randomly, [vol.] Any L. Rev. [page], n.[footnote] (date).

34 M. Price, A Practical Manual of Standard Legal Citations iii (2d ed. 1958), quoted in Cooper, supra note 12 , at 3 . 
research materials." ${ }^{35}$ Some advocates of the citation footnote describe its value as follows: "[T]o one digging into the bowels of the law, a fat footnote is a mother lode, a vein of purest gold." 36 In a somewhat more cynical vem, we should remember Fred Rodell's assertion: "Every legal writer is presumed to be a har until he proves himself otherwise with a flock of footnotes." 37

If footnotes are indeed intended to serve this bibliographic function, then we should desire accurate signals, indicating precisely the relationship between the statement in the text and the contents of the cited materials. In that case, the Bluebook, at least in theory, is more useful. In reahity, however, anyone who has ever struggled-or, worse yet, fought with an editorover the often metaphysical distimctions between, for example, "[no signal]" and "see" or "but see" and "but cf." feels fully prepared to dispute just how many angels can dance on the head of a pin. ${ }^{38}$

Furthermore, whatever (false?) sense of precision the prescriptions of the Bluebook may provide, they depend for their usefulness on consistency across space and time. Unfortunately, temporal consistency is lacking, for the array of available signals and their prescribed meaning has changed between various editions of the Bluebook. As one commentator poimts out, ${ }^{39}$ in the twelfth edition, "see also" referred to authority that "provides background to a question analogous to that examined in text." 40 By the thirteenth edition, the meaning had changed to "constitutes additional source material that supports the proposition." ${ }^{\prime 1}$ Thus, a researcher seeking

35 Slomanson, Footnote Logic in Law Review Writing: Previously Unaddressed in the Criminal Justice System, 9 Criin. Just. J. 65, 68 (1986).

36 Fuld, A Judge Looks at the Law Review, 28 N.Y.U. L. Rev. 915, 919 (1953), quoted in Martim, supra note 8, at 1097. One shudders to think of the result of subjecting this metaphor to Jack Balkin's deconstructive zeal. See Balkin, supra note 3.

37 Rodell, supra note 1 , at 41 .

38 In a face-off between the editors of the Maroon Book and the Bluebook, the former focused on introductory signals; the latter used no signals. Law Review Conference, supra note 16.

For a soinewhat cynical translation of the meaning of the various Bluebook signals, see Lushing, supra note 22, at 601 :

Use no signal when you've got the guts. Use e.g. when there are other examples you are too lazy to find or are skeptical of unearthing. Use accord when one court has cribbed from the other's opinion. Use see when the case is on all three's. Use cf. when you've wasted your time reading the case. Insert but in front of these last two when a frown instead of a sinile is indicated.

39 Kanter, Putting Your Best Footnote Forward, Barrister, Spring 1982, at 42, 52.

40 Bluebook, supra note 4, at 7 (12th ed. 1976), quoted in Kanter, supra note 39, at 52.

41 Bluebook, supra note 4, at 8 (13th ed. 1981), quoted in Kanter, supra note 39, at 52. A category presumably separable from "authority [that] directly supports the proposition," which should be introduced by "see." Authors, of course, have a vested interest in arguing for 
to comprehend the precise meaning of a source introduced by the signal "see also" presumably must compare the date of publication of the article within which the citation appears to the date of publication of the thirteenth edition of the Bluebook.

Such transcendental nonsense may be merely academic when source and citation are themselves academic productions. When the citation is in a judicial opimion, however, Court III may need to divine the meaning Court II meant to attribute to an opmion of Court I by parsing the imtroductory signal used by Court II. ${ }^{42}$ Were Court II, however, to have shifted to the Maroon Book, wherem citations may be introduced by any descriptive language that "explain[s] its force and or [sic] purpose," 43 Court III would be freer to reinterpret the precedents of Courts I and II.

All the above assumed that the fuuction of footnotes was to support the text and thus that the function of siguals was to indicate the relationship between statements made in the text and statements made in, or imphed by, the cited materials. In fact, however, this is only one of the purposes served by citation footnotes. ${ }^{44}$

Footnotes frequently serve to indicate a relationship, not merely between texts, but between the author of the article and the authors of the cited materials. This sort of strategic footnoting has two forms. An established author, seeking to make a lateral move into a related field, may erect a battlement of footnotes. A controversial stateinent is followed by a lengthy note referring the reader generally to writings by the recognized authorities in the new field. ${ }^{45}$ A less-established author, especially in a tenure article, may cite to as many as possible of the extant writings by established legal scholars. Such footnotes indicate one's grasp of the hiterature. They also enhance the possibility that an outside reviewer will happily find her own

\footnotetext{
"see" and thus avoiding further dispute over the content of "see also's" "encouraged" parenthetical. Bluebook, supra note 4 , at 9 .

42 Chemical Bank v. Arthur Andersen \& Co., 726 F.2d 930, 938 n.14 (1984) (holding that Supreme Court citation of earlier Judge Wright concurrence, introduced by a cf., was an endorseinent since the Bluebook calls for the use of cf. only for a source "sufficiently analogous to lend support"); see also Book Note, 32 N.Y.L. Sch. L. Rev. 199, 200 \& nn.8-12 (1987) (citing other instances where the Bluebook was used as authority in deciding legal questions).

43 Maroon Book, supra note 18 , at 12.

44 Textual footnotes (such as this one) are outside the scope of this Book Review. I note, however, that they, too, have multiple meanings and purposes. For example, iny colleague, George Mundstock, says that footnotes are the place in which he responds to those critical voices that energe from his subconscious as he writes the text. This may explain why "id." appears only in the footnotes of law review articles. But see Lawrence, The Id, The Ego and Equal Protection: Reckoning with Unconscious Racisin, 39 Stan. L. Rev. 317 (1987).

45 See, e.g., R. Posner, Law and Literature: A Misunderstood Relation 40 n.18 (1988) (literature on Hamlet).
} 
work cited. ${ }^{46}$ Unlike the situation in Meiklejohn's town meeting, it often appears that it is at least as important that the appropriate people be cited as that the appropriate statements be supported. ${ }^{47}$

Previous writers occasionally have alluded to the hidden purposes of citations or the ways in which the demands of editors (or future tenure committees) have influenced the forms of law review writing. Professor Rotunda noted with amused disdam that "any unread article may still be cited."48 On a far more serious note, Professor Delgado criticized the closed, selfreferential circle of white male scholars, published in the leading law reviews, who wrote about minorities but failed to cite to works by minority scholars. ${ }^{49}$

Once we recognize the multiple purposes served by the decision to cite to particular sources, the inadequacy of the range of introductory signals in the Bluebook becomes readily apparent. Hereby is my modest proposal-an alternative to the Bluebook and/or a supplement to the Maroon Book-of useful introductory signals.

1. Will not see in: Many authors have said something along the order of "no court has ever recognized the relationship between $X$ and $Y$," and then faced an editor's demand for support for the proposition. One could try "See, e.g., 452 F. Supp. 761," or any other randomly chosen reporter page. ${ }^{50}$

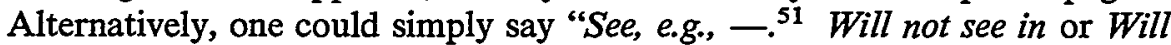
not see in, e.g., provide a more explicit alternative. ${ }^{52}$ If desired, an assertive

46 A footnote here would be vulgar.

47 A. Meiklejohn, Free Speech and its Relation to Self-Government 25 (1948) (asserting that what is important for free speech is not that everyone gets to speak but that everything worth saying be said). Anyone who has attended faculty meetings will recognize that the latter is a tiny subset of the former.

48 Rotunda, Law Reviews-The Extreme Centrist Position, 62 Ind. L.J. 1, 3 n.7 (1986).

49 Delgado, The Imperial Scholar: Reflections on a Review of Civil Rights Literature, 132 U. Pa. L. Rev. 561 (1984); see also Matsuda, Affirmative Action and Legal Knowledge: Planting Seeds in Plowed-up Ground, 11 Harv. Women's L.J. 1 (1988) ("One can discern the landscape of segregated legal knowledge by reading the law reviews of elite law schools."). These Reflections appear to have had reflections of their own, in a hall of (distorting) inirrors. See Kennedy, Racial Critiques of Legal Academia, 102 Harv. L. Rev. 1745 (1989) (challenging, inter alia, the claim that the failure of white scholars to cite minority scholarship is an indication of racism). But don't you wish you could see/hear R. Delgado \& $\mathrm{K}$. Crenshaw, Remarks at Emerging Voices Conference (Sept. 1989).

50 Strasser, supra note 10, at 507 n.2 ("See, e.g., The N.Y. Times").

51 Don't Cry, supra note 10, at 1554 n.5.

52 The related signal, do not see, e.g., [this is not a signal; cf. Magritte] may also have other uses. Fred Schauer has suggested that it might have served as a still more ironically selfdeprecatimg introductory signal in Schauer, Constitutional Conventions (Book Review), 87 Mich. L. Rev. 1407, 1410 n.l (1989) (following textual reference to treatises of Blackstone, Story, Corbin, Prosser, Loss, etc. with footnoted "See also??? F. Schauer, The Law of Obscenity (1976)."). 
variant signal could be Trust me, I've looked for it.

2. See, e.g., [future volume] F.2d [future page]: When the author has proposed a solution for the relationship between $\mathrm{X}$ and $\mathrm{Y}$, she may well expect it to be adopted by the courts. This signal indicates that expected outcome. A variant for the more self-assured would be see, e.g., $111 \mathrm{~S}$. Ct. 1; for the more academically ambitious, consider the variation see, e.g., $77 \mathrm{Va}$. L. Rev. 1.53

3. See, sort of: This is the signal for the citation that the editor probably insisted on, but which only the most extraordinarily compulsive reader would examine. The more honest signal would be "The law review editors made me cite to ...." Innumerable examples could be cited; the kindest are the pair of references to the Oxford English Dictionary in the first University of Pennsylvama Law Review Aside. ${ }^{54}$ Agam, variant signals are available: see if you must or trust me, I've looked it up. An author witl enough clout miglit bludgeon the editors into allowing the footnote I'm the expert; no one worth citing would dare contradict me.

4. See, randomly: This is the proposed reference to the uncollected works of an author who has had a good idea and reworked it througliout lis career. Rather than clioose any one exeinplar, to which the reader may not liave ready access, cite as follows: See, randomly, Smith, Law Reviews (19xx19yy). This signal miglit be viewed as the collective equivalent of passim.

5. Really should see: Once we recognize that not every positive Bluebook signal is an endorseinent by the autlior, we can understand the need for a signal like this. ${ }^{55}$ A more forceful variation, especially for the nonstandard source, might be: she's gotta see it! When tlie message is that the source isn't directly on point to the topic of the article, but you really loved it and want your readers to share the excitement, the appropriate signal might be see, for the hell of it.

6. Pretend to have seen: In every field there are the classic works that one would read if the timie ever magically appeared but that, in the meantine, cannot be ignored if one is to appear scholarly. ${ }^{56}$ To cite thein, but with this

53 Thanks to the miracles of modern word-processing, no one will ever know if this illustrious law review was thc stated standard of excellence before its editors graciously accepted this Book Review.

54 Don't Fly, supra note 10, at $1474 \mathrm{nn} .1$ \& 4.

55 This signal would have saved some print for Nowak, Woe Unto You, Law Reviews!, 27 Ariz. L. Rev. 317, $318 \mathrm{n} .1$ (1985) ("I would advise those few of you who may be interested in learning more about Fred Rodell to ....").

56 The sources that properly fall within this signal are, of course, culturally contingent. Cf. Regina v. Dudley, 14 Q.B.D. 273, 287 (1884) ("'i]t would be a very easy and cheap display of commonplace learning to quote from Greek and Latin authors, from Horace, from Juvenal, from Cicero, from Euripides"). (You didn't really expect a list of examples, did you?) 
signal, is to evoke the attitude of the Enghish landed gentry, whose tradition was to hive well, but not to pay the bills.

If one wishes to become quite subtle and convoluted, one might have a variant signal (perhaps act as though you have seen) for still more obscure sources that the people you pretend to have seen would have pretended to have seen.

7. Don't you wish you could see: How often have you seen a cite to a work, sometimes by a famous person, frequently with an intriguing title, followed by the parentheticals (unpublished manuscript) (on file at the $\mathrm{X}$ Law Review)? Signals like see or see also are a cruel joke: if you were meant to see it, you would have been in the inner circle to whom the manuscript was distributed. Often, ouly the signal suggested here fully expresses the author's relationship with the source (and the reader). ${ }^{57}$

The addition of these new signals to the available vocabulary is not, of course, an unmitigated good. Sometimes, standard signals like "see" or "see also" can be useful for what they do not say. An author may, for example, be unsure if a cited work deserves a "really see" cite, or she may consider it impolitic to indicate publicly, via a "see, sort of" cite, its marginal value. In such cases, the standard citation forms have the virtue of using linguistic ambiguity to avoid confronting delicate theoretical or pohtical issues. ${ }^{58}$

The prior discussion is largely nonsense, but it is not, I liope, the transcendental nonsense criticized long ago by Felix Cohen. ${ }^{59}$ It is, rather, a form of immanent nonsense, playing upon feelings we have all had about the enterprise in which we are engaged. As my colleagne, Robert Rosen, poimted out,

57 One presumably self-mocking example is in Book Note, supra note 10, at $1328 \mathrm{n} .19$ ("see conversations with the Executive Editors of the Harvard Law Review (March 5, 1987; October 7, 1987; March 1, 1988)"). Cites to conversations can be seen as thoughtful acknowledgments of the contributions of others or as strategic positioning, depending on the relative status of writer and conversant. See Austin, supra note 15, at nn.78-80.

Professor Frances Olsen's book review of Catharine MacKinnnon's Feminism Ununodified (1987) presents another vivid example of a citation that defines a closed community of scholars from which the reader is excluded. Olsen, Feminist Theory in Grand Style (Book Review), 89 Colum. L. Rev. 1147, $1176 \mathrm{n} .117$ (1989) (noting that the editor of Olsen's piece in the Texas Law Review suggested by way of a comnient on a galley proof that "a statement about nooks and crannies might be the only thing people would quote from the article and that the force of [the] critique would be lost").

If there are any such unpublished manuscript cites in my prior works, I hereby renounce them. Cf. Gabel \& Kennedy, supra note 25 (on renouncing).

A distinct genre is the cite to the not-yet-published manuscript, often the result of collegiality among those working concurrently on related topics. It is essential to renieniber to change the footnote from the working draft version (forthcouning Hotshot L. Rev.).

s8 See U.S.C. passim.

59 Cohen, Transcendental Nonsense and the Functional Approach, 35 Colum. L. Rev. 809 (1935). 
the signals provided us by the Bluebook fail to capture the range of responses we have to the sources we cite. Perhaps one more new signal is needed to do so. ${ }^{60}$

60 Feel, e.g., Rodell, supra note 1 or Balkin, supra note 3. My response to each of these is complex, textured and emotive. It is an imagined relation with the author as well as the text and involves far more than the abstract, visualized connection evoked by the term "see." See and feel, generally, 76 Va. L. Rev. 1099 (1990). 